Supplement of

\title{
Simulating the feedback between corrosive gas generation and water availability for the evaluation of radionuclide mobility in the context of radioactive waste disposal
}

\author{
Laurin Wissmeier and Joachim Poppei \\ Correspondence to: Laurin Wissmeier (l.wissmeier@csd.ch)
}

The copyright of individual parts of the supplement might differ from the article licence. 


\section{Simulating the feedback between corrosive gas generation and water availability for the evaluation of radionuclide mobility in the context of radioactive waste disposal}

safeND Interdisciplinary Research Symposium

10.11.2021 - 12.11.2021 Berlin

Laurin Wissmeier, Joachim Poppei, Gerhard Mayer
CSDENGINEERS INGENIOUS BY NATURE 


\section{The importance of gas generation for radioactive waste}

\section{disposal}

+ May affect the mobility of dissolved and volatile radionuclides through changes in phase saturation

+ May affect mobility of dissolved and volatile radionuclides through changes in geochemical conditions (Eh, $\mathrm{pH}_{\mathrm{m}}$, etc.)

+ May induce advective transport

+ May affect the mechanical stability of the host rock and open up dilatant transport pathways

+ May affect the integrity of technical and geotechnical barriers 


\section{Perception of gas generation as kinetic geochemical reactions}

Cellulose oxidation by molecular oxygen (c_o)

Cellulose oxidation by nitrate (c_n)

Cellulose oxidation by sulfate reduction (c_s)

Cellulose oxidation by $\mathrm{Fe}$ (III) reduction (c_f)

Methane generation from cellulose (c_m)

Plastics oxidation by molecular oxygen (p_o)

Plastics oxidation by nitrate $\left(p \_n\right)$

Plastics oxidation by sulfate reduction (p_s)

Plastics oxidation by $\mathrm{Fe}(\mathrm{III})$ reduction $\left(\mathrm{p}_{-} \mathrm{f}\right)$

Methane generation from plastics ( $\left.p_{-} m\right)$

Hydrogen oxidation by $\mathrm{Fe}(\mathrm{III})$ reduction ( $\left.\mathrm{h} \_\mathrm{o}\right)$

Hydrogen oxidation by $\mathrm{CO} 2$ reduction (h_m)

Hydrogen oxidation by sulfate reduction ( $\left.h \_s\right)$

\section{Aerobe corrosion of C-steel (cs_o)}

Anaerobe corrosion of C-steel (cs_h)

Reduction of $\mathrm{Fe}$ (III) with C-Steel (cs_r)

Aerobe corrosion of stainless steel (ss_o)

Anaerobe corrosion of stainless steel (ss_h)

Reduction of $\mathrm{Fe}(\mathrm{III})$ with stainless steel (ss_r)

Oxidation of $\mathrm{Fe}(\mathrm{II})$ with hydrogen (Schikorr reaction) (fe_sch)

Iron sulfide precipitation (fe_sul)

Anaerobe corrosion of aluminium (al_h)
$\mathrm{C} 6 \mathrm{H} 10 \mathrm{O} 5+6 \mathrm{O} 2=>5 \mathrm{H} 2 \mathrm{O}+6 \mathrm{CO} 2$

$\mathrm{C} 6 \mathrm{H} 10 \mathrm{O} 5+4.8 \mathrm{NO} 3-+4.8 \mathrm{H}+=>2.4 \mathrm{~N} 2+7.4 \mathrm{H} 2 \mathrm{O}+6 \mathrm{CO} 2$

$\mathrm{C} 6 \mathrm{H} 10 \mathrm{O} 5+3 \mathrm{SO} 4-2+6 \mathrm{H}+=>3 \mathrm{H} 2 \mathrm{Sg}+5 \mathrm{H} 2 \mathrm{O}+6 \mathrm{CO} 2$

$\mathrm{C} 6 \mathrm{H} 10 \mathrm{O} 5+24 \mathrm{FeOOH}+7 \mathrm{H} 2 \mathrm{O}=>24 \mathrm{Fe}(\mathrm{OH}) 2+6 \mathrm{CO} 2$

$\mathrm{C} 6 \mathrm{H} 10 \mathrm{O} 5+3 \mathrm{H} 2 \mathrm{O}=>4 \mathrm{H} 2+2 \mathrm{CH} 4+4 \mathrm{CO} 2$

$\mathrm{C} 2 \mathrm{H} 4+3 \mathrm{O} 2=>2 \mathrm{H} 2 \mathrm{O}+2 \mathrm{CO} 2$

$\mathrm{C} 2 \mathrm{H} 4+2.4 \mathrm{NO}^{-}-2.40 \mathrm{H}+=>1.2 \mathrm{~N} 2+3.2 \mathrm{H} 2 \mathrm{O}+2 \mathrm{CO} 2$

$\mathrm{C} 2 \mathrm{H} 4+1.5 \mathrm{SO} 4-2+3 \mathrm{H}+=>1.5 \mathrm{H} 2 \mathrm{~S}+2 \mathrm{H} 2 \mathrm{O}+2 \mathrm{CO} 2$

$\mathrm{C} 2 \mathrm{H} 4+12 \mathrm{FeOOH}+4 \mathrm{H} 2 \mathrm{O}=>12 \mathrm{Fe}(\mathrm{OH}) 2+2 \mathrm{CO} 2$

$\mathrm{C} 2 \mathrm{H} 4+2.666667 \mathrm{H} 2 \mathrm{O}=>3.333333 \mathrm{H} 2+0.666667 \mathrm{CH} 4+1.333333 \mathrm{CO} 2$

$\mathrm{H} 2+2 \mathrm{FeOOH}=>2 \mathrm{Fe}(\mathrm{OH}) 2$

$\mathrm{H} 2+0.25 \mathrm{CO} 2=>0.25 \mathrm{CH} 4+0.5 \mathrm{H} 2 \mathrm{O}$

$\mathrm{H} 2+0.25 \mathrm{SO} 4-2+0.5 \mathrm{H}+=>0.25 \mathrm{H} 2 \mathrm{~S}+1 \mathrm{H} 2 \mathrm{O}$

$\mathrm{Fe}(0)+0.5 \mathrm{H} 2 \mathrm{O}+0.75 \mathrm{O} 2=>1 \mathrm{FeOOH}$

$\mathrm{Fe}(0)+1.333333 \mathrm{H} 2 \mathrm{O}=>1.333333 \mathrm{H} 2+0.333333 \mathrm{Fe} 3 \mathrm{O} 4$

$0.5 \mathrm{Fe}(0)+1 \mathrm{FeOOH}=>0.5 \mathrm{H} 2+0.5 \mathrm{Fe} 3 \mathrm{O} 4$

$\mathrm{Fe}(0)+0.5 \mathrm{H} 2 \mathrm{O}+0.75 \mathrm{O} 2=>1 \mathrm{FeOOH}$

$\mathrm{Fe}(0)+1.333333 \mathrm{H} 2 \mathrm{O}=>1.333333 \mathrm{H} 2+0.333333 \mathrm{Fe} 3 \mathrm{O} 4$

$0.5 \mathrm{Fe}(0)+1 \mathrm{FeOOH}=>0.5 \mathrm{H} 2+0.5 \mathrm{Fe} 3 \mathrm{O} 4$

$\mathrm{Fe}(\mathrm{OH}) 2=>0.333333 \mathrm{H} 2+0.333333 \mathrm{Fe} 3 \mathrm{O} 4+0.666667 \mathrm{H} 2 \mathrm{O}$

$\mathrm{H} 2 \mathrm{Sg}+1 \mathrm{Fe}(\mathrm{OH}) 2=>2 \mathrm{H} 2 \mathrm{O}+1 \mathrm{FeS}$

$\mathrm{Al}(0)+4 \mathrm{H} 2 \mathrm{O}=>1.5 \mathrm{H} 2+1 \mathrm{Al}(\mathrm{OH}) 4-+1 \mathrm{H}+$ 


\section{Feedback of corrosive gas generation and water} availability

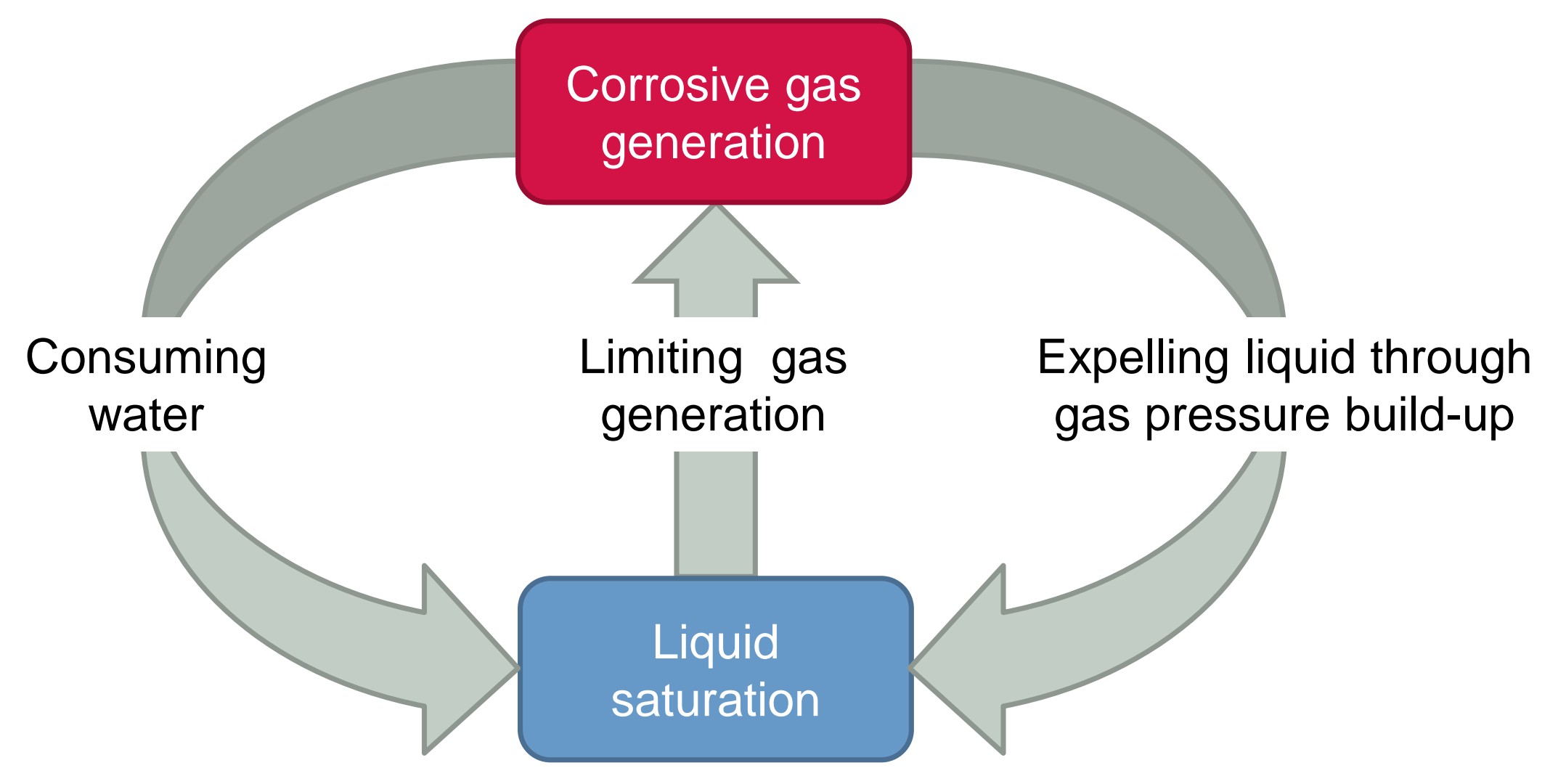




\section{Literature overview}

+ Xu et al. (2008): Corrosion-induced gas generation in a nuclear waste repository: Reactive geochemistry and multiphase flow effects. Applied Geochemistry, 23, 34233433. doi:10.1016/j.apgeochem.2008.07.012

+ Croisé et al. (2011): Impact of water consumption and saturation-dependent corrosion rate on hydrogen generation and migration from an intermediate-level radioactive waste repository. Transport in Porous Media, 90, 59-75. doi:10.1007/s11242-011-9803-0

+ Leupin et al. (2016): An assessment of the possible fate of gas generated in a repository for low- and intermediate-level waste. Nationale Genossenschaft für die Lagerung radioaktiver Abfälle (NAGRA), Nagra Working Report, NTB 16-05.

+ Huang et al. (2021): Two-phase transport in a cemented waste package considering spatio-temporal evolution of chemical conditions. npj Materials Degradation, 5, 4. doi:10.1038/s41529-021-00150-z 


\section{What's new}

+ Implementation in PFLOTRAN: A Massively Parallel Reactive Flow and Transport Model for Describing Surface and Subsurface Processes

+ Application to radioactive waste management in salt host rock 


\section{PFLOTRAN}

+ A massively parallel reactive flow and transport model for describing surface and subsurface processes

- Multicomponent 2-Phase flow: GENERAL mode

- 2-phase water and supercritical $\mathrm{CO}_{2}$ flow: MPHASE mode

+ Designed $a b$ initio with reactive transport capabilities

+ Designed for application to salt host rock

- Intended as replacement for several other codes currently used in the periodic performance assessment and recertification process for the WIPP

+ Developed in close cooperation with the team behind the PETSc solver suite

+ Developed by consortium of Los Alamos National Lab, Oak Ridge National Lab, Pacific Northwest National Lab and Sandia National Labs

+ The code is open source; available at https://bitbucket.org/pflotran/pflotran/wiki/Home 


\section{Reaction equations}

+ Simplified anoxic iron corrosion reaction with Magnetite as corrosion product:

$$
3 \mathrm{Fe} e^{0}+4 \mathrm{H}_{2}^{+I} \mathrm{O}^{-I I} \rightarrow\left(\mathrm{Fe}^{+I I} \mathrm{Fe}_{2}^{+I I I}\right) \mathrm{O}_{4}^{-I I}+4 \mathrm{H}_{2}^{0}
$$

+ Conceptualized as kinetic reaction with rate:

$$
r_{0}=\frac{d m_{F e^{0}}}{d t}=\frac{k \cdot A \cdot \rho_{F e^{0}}}{M_{F e^{0}}}
$$

\ Linear reduction of corrosion rate at onset:

$$
r_{1}=r_{0} \cdot\left\{\begin{array}{cc}
9.1-9 \cdot m_{F e} & 0.9 \cdot m_{F e_{0}^{0}} \leq m_{F e}<m_{F e_{0}^{0}} \\
1 & m_{F e} \leq 0.9 \cdot m_{F e_{0}^{0}}
\end{array}\right.
$$

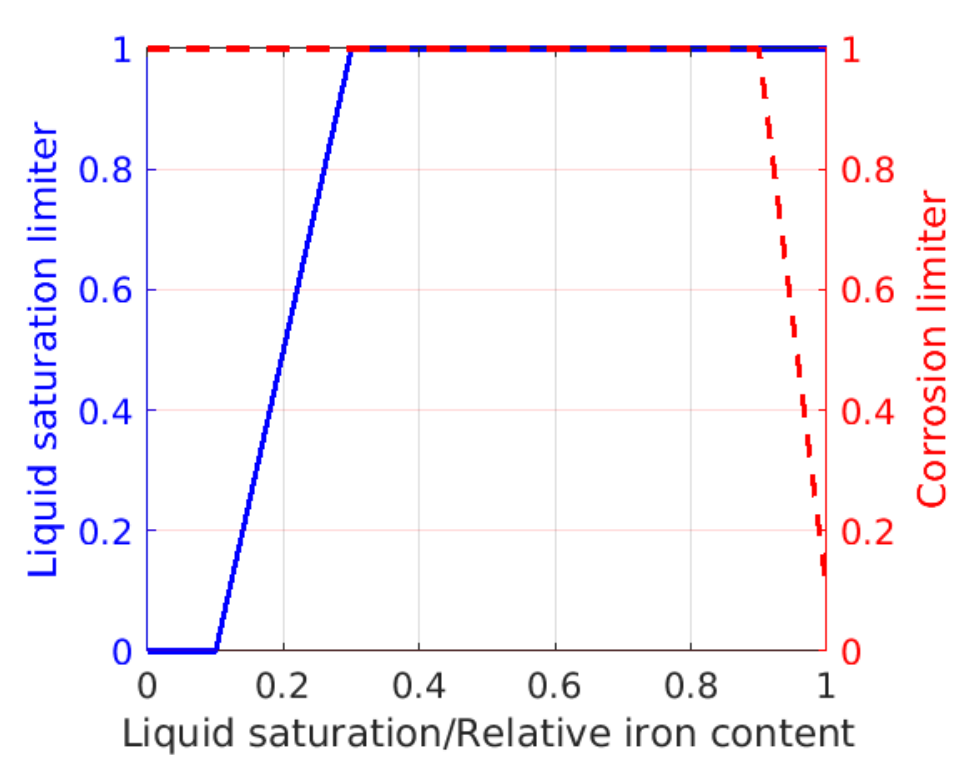

+ Linear reduction of corrosion rate with decreasing liquid content (similar reduction with depletion of iron inventory):

$$
r_{2}=r_{1} \cdot\left\{\begin{array}{cc}
0 & S_{l} \leq S_{l, 1} \\
\frac{S_{l}-S_{l, 1}}{S_{l, 2}-S_{l, 1}} & S_{l, 1}<S_{l}<S_{l, 2} \\
1 & S_{l} \geq S_{l, 2}
\end{array}\right.
$$

- Differentiation of 3 different iron pools with different $F e_{0}^{0}$, different $A_{0}$ and different $k$ 


\section{Implementation in PFLOTRAN}

+ Using object-oriented coding provisions with encapsulation, inheritance, and polymorphism in PFLOTRAN for user-defined source/sink terms: SRCSINK_SANDBOX

+ SRCSINK_SANDBOX: Fortran 90 class with access to all important process variables

t Adapting directly the residuals in the numerical solution for the gas and liquid phases as well as temperature

+ Output of process variables to result files (HDF5, ASCII etc.)

+ Direct visualization in Tecplot, Vislt and ParaView

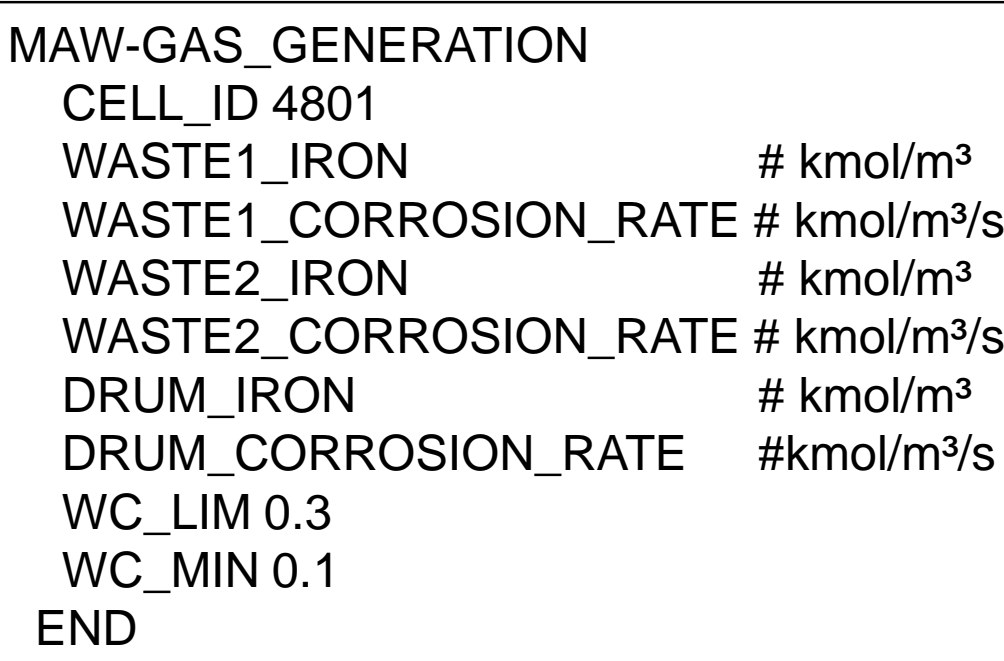




\section{Application example}

+ Simulation modified on the basis of benchmark calculations between TOUGH2 and PFLOTRAN

+ Original simulations published in Namhata, A., Li, C., Papafotiou, A.: Model-based assessment of repository induced effects in the vicinity of repositories for SF/HLW. In Management of Spent Fuel from Nuclear Power Reactors, IAEA, International Atomic Energy Agency (IAEA). ISBN 0074-1884

+ Emplacement tunnel in clay host rock with

- Steel canister and iron reinforcement

- 2 types of Bentonite backfill

- Stylized EDZ

- Confining units

- Rectangular 2D grid with octree grid refinement

Material ID at $20 \mathrm{y}$

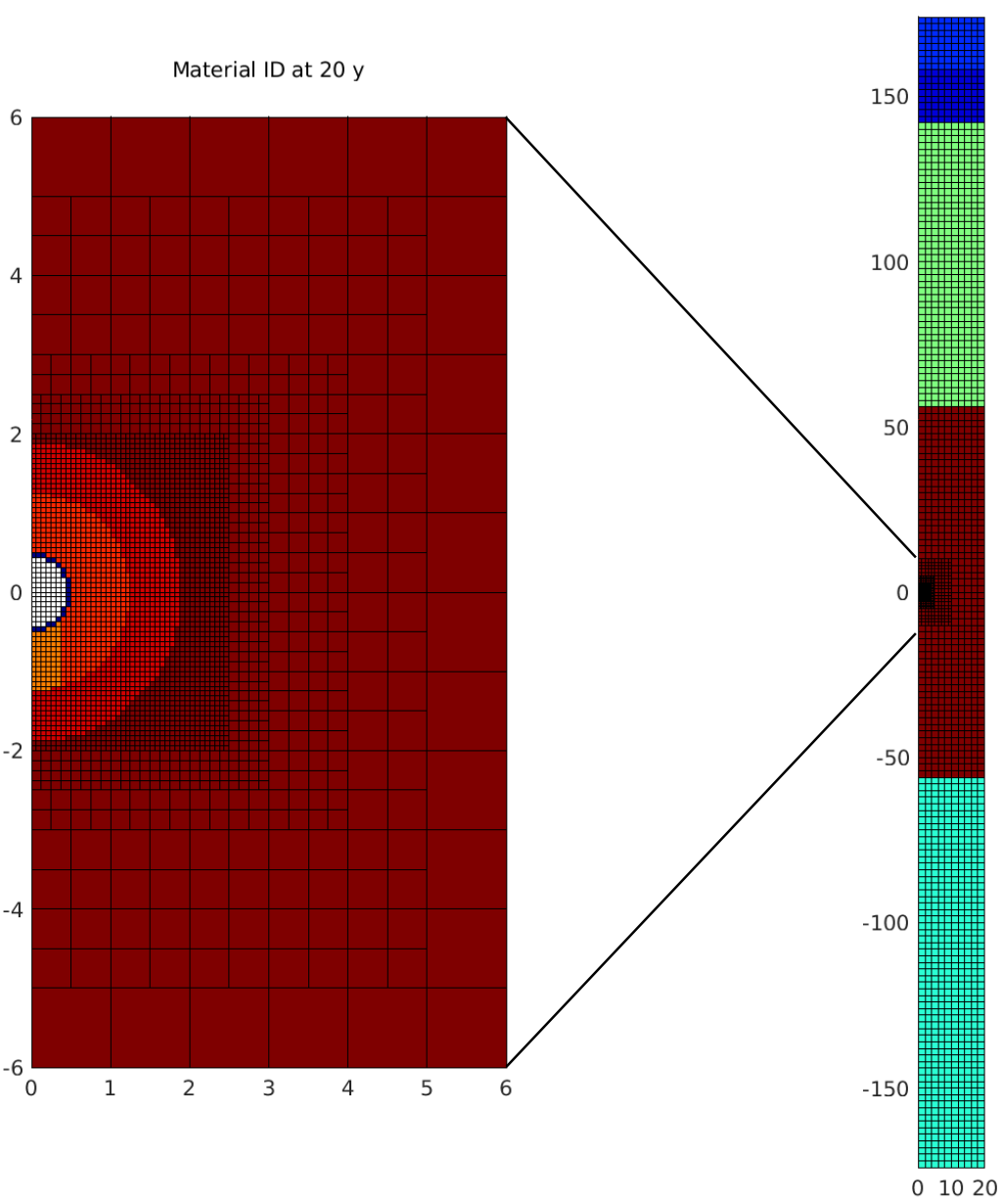

Material ID at $20 \mathrm{y}$ 


\section{CSDENGINEERS ${ }^{+}$}

Comparison of model results with and without water consumption for different locations
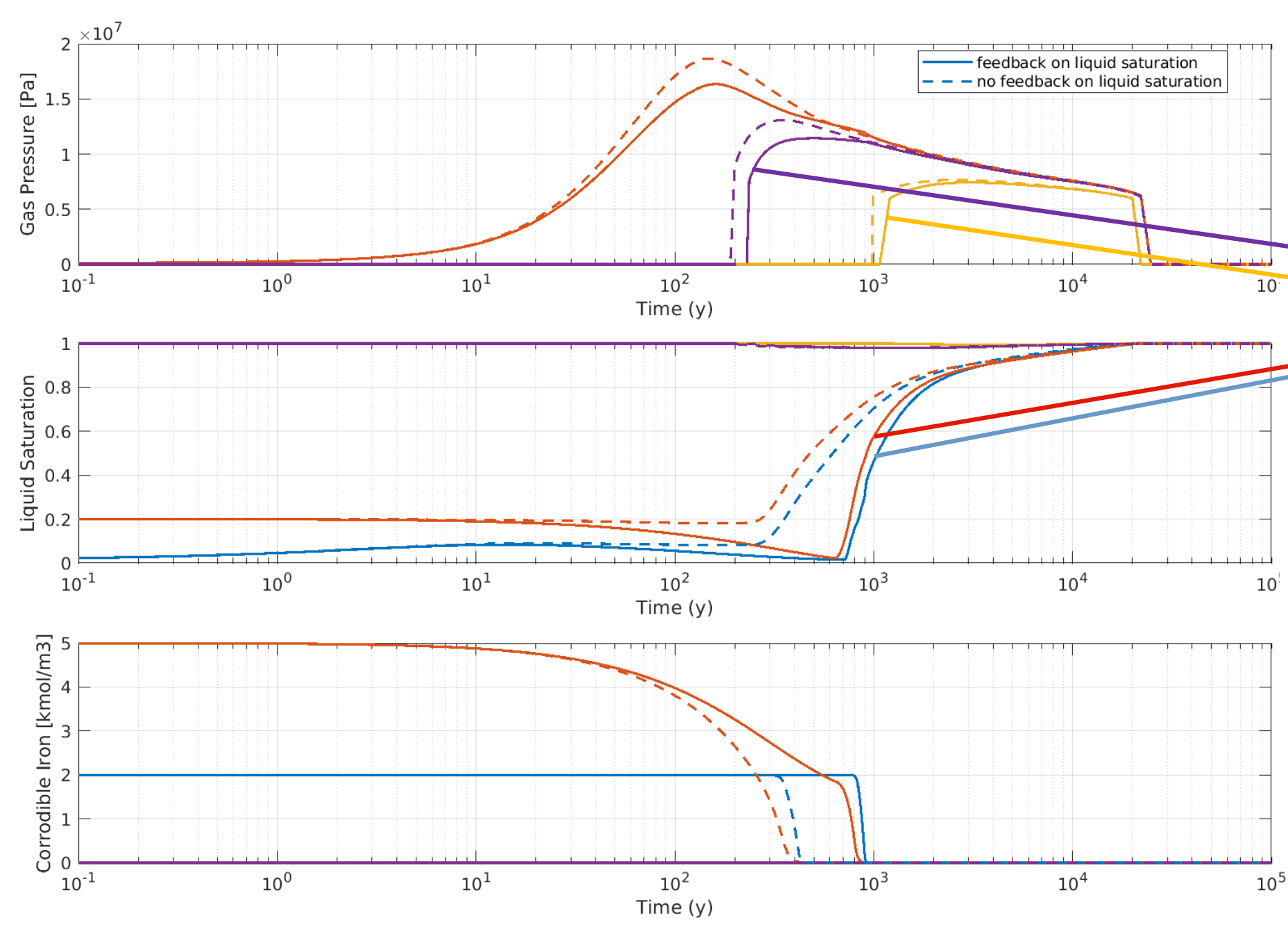


\section{CSDENGINEERS +}

Comparison of model results:

Evolution of corrodible iron content
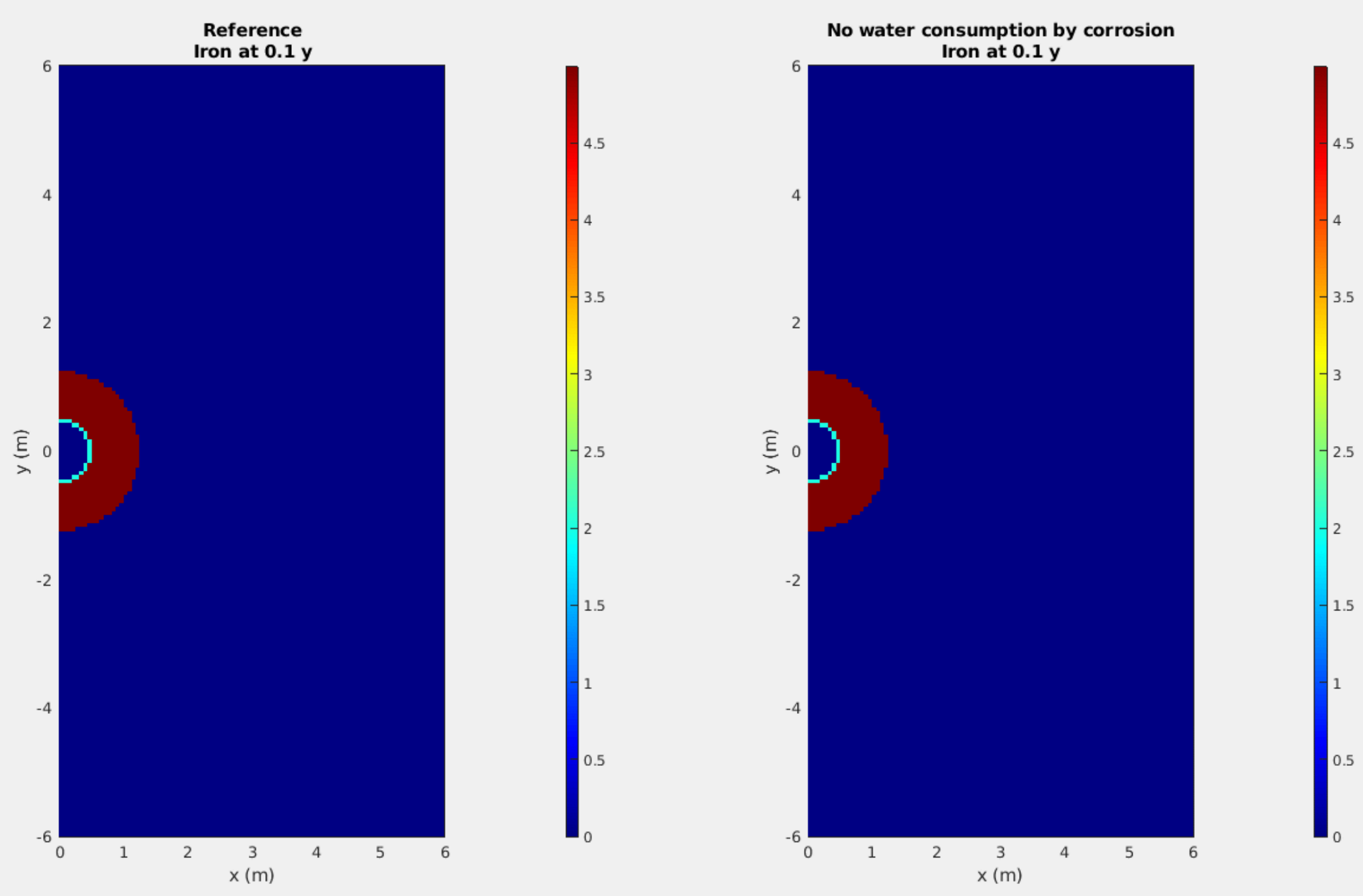


\section{CSDENGINEERS +

Comparison of model results:

Evolution of liquid saturation
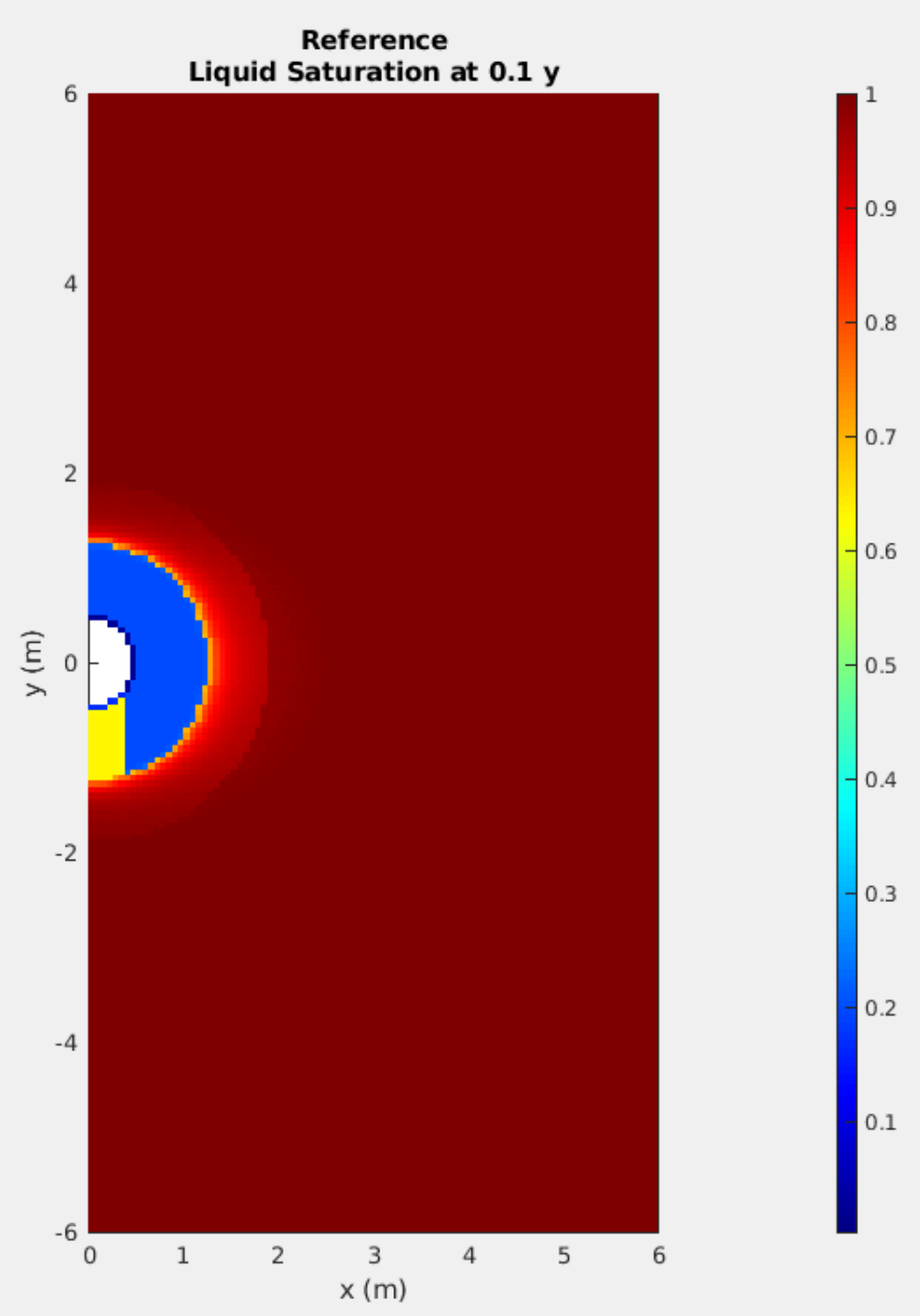

No water consumption by corrosion

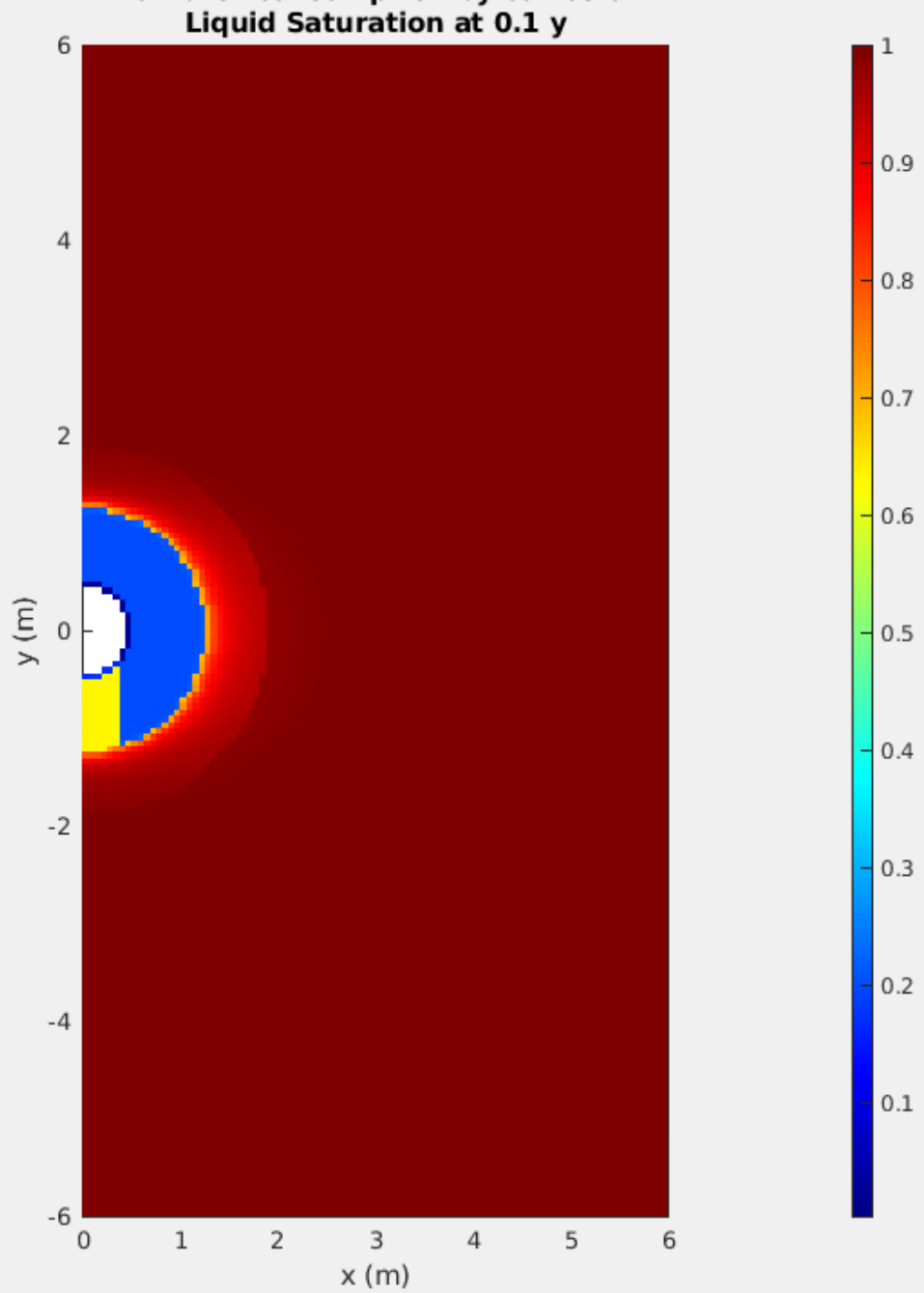


Comparison of model results:

Evolution of gas pressure
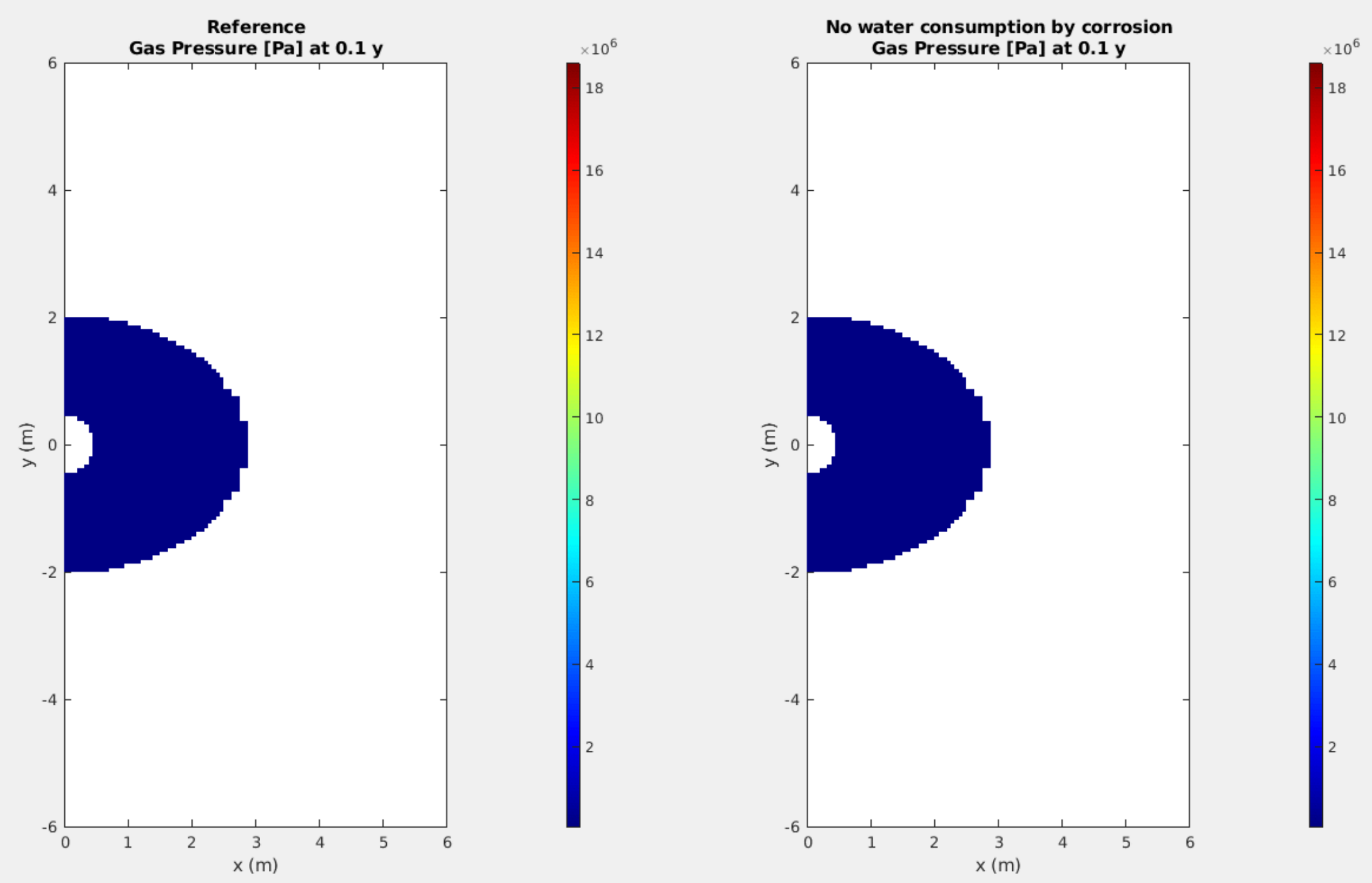


\section{Summary}

+ We have shown the importance to consider also water as educt / product of gas generating reactions in the context of 2-phase flow simulations

+ We have detailed the implementation of water consuming anoxic corrosion into the flow and reactive transport simulator PFLOTRAN

+ We have given an application example for a generic repository layout

+ For further information, send an e-mail to:

\section{l.wissmeier@csd.ch}

\section{Thank you for your attention!}

